\title{
Study of Methods and Development of Technological Scheme for Heat Removal from Rock Waste Dump
}

\author{
Saik Pavlo ${ }^{1, a}$ \\ ${ }^{1}$ National Mining University, Dnipro, Ukraine \\ asaik.nmu@gmail.com
}

Keywords: recovery energy source, heat pump, geosystem, underground coal gasification

\begin{abstract}
The aim of this paper is to study the methods and develop technological scheme for thermal energy removal from coal mine rock waste dumps. The prospects of renewable energy sources development in Ukraine are analyzed. A number of available ways for using the sources of waste heat of mining enterprises, namely: outlet ventilation flow, mine water and other rock waste dumps, are investigated. The technological scheme of heat recovery from rock waste dump using heat pumps, which are component segments of the heat pump geosystem on the basis of borehole underground coal gasification, is developed.
\end{abstract}

\section{Introduction}

Consumption of energy resources in the nearest time will provoke their rapid rise, accompanied by their gradual exhaustion. This situation requires a search of internal reserves based on renewable energy. Energy crisis prompts European countries for searching an alternative source of renewable energy. Important part of those efforts is conducting of integration research and development of road maps for sustainable energy use for whole continents because the supply of sustainable energy is one of the main challenges in modern world (1).

Today, in the world due to the depletion of natural energy resources, the scientific community is increasingly considering issues related to the promising development of renewable energy sources (RES). Their share in the energy balance of Ukraine is less than 3\%. (Fig. 1) (2).

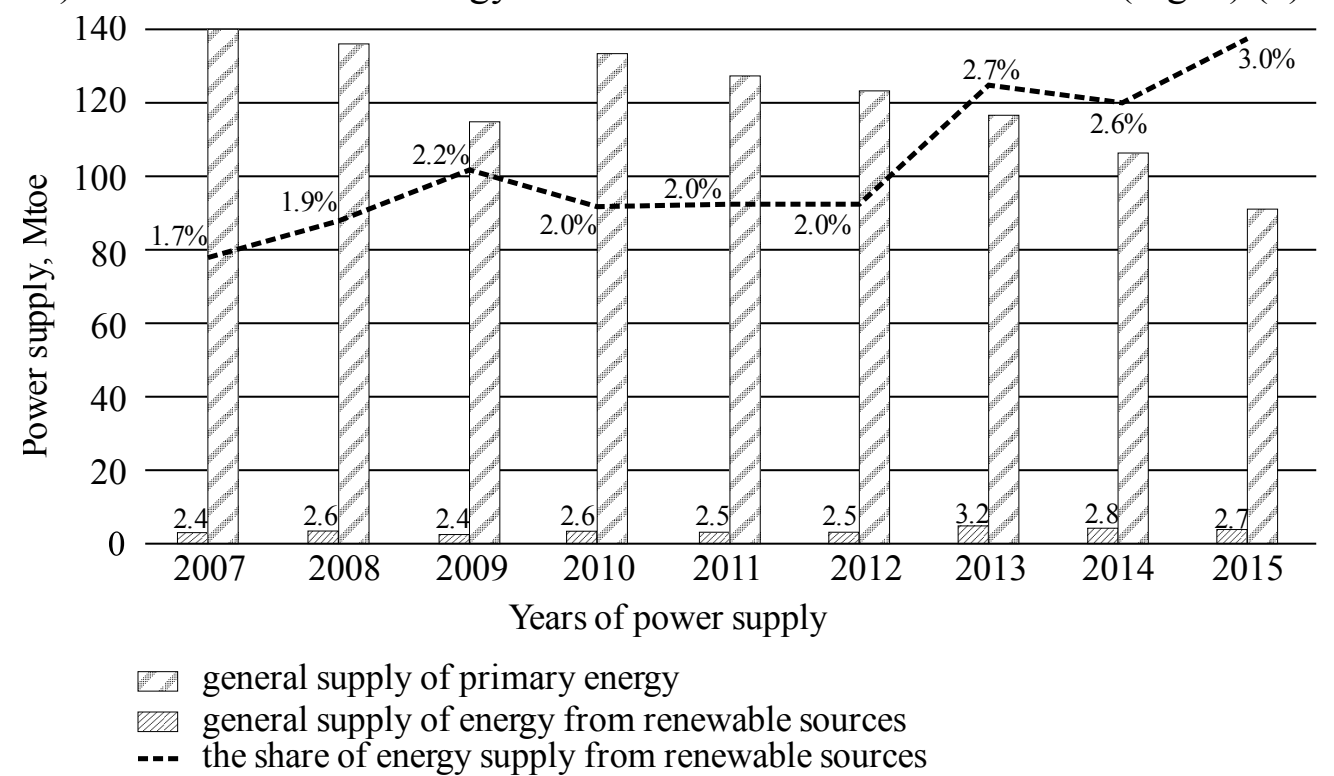

Fig. 1. Energy consumption on the basis of renewable energy sources

In the structure of renewable energy production in 2015, hydropower occupied the most significant share (Fig. 2). Modern RES capacities tend to grow steadily. The greatest dynamics of development indicate on the solar power industry. In 2016, the power of such solar stations increased by $18 \%$ compared to 2015 , from $431 \mathrm{MW}$ to $530 \mathrm{MW}$ [2].

On the basis of renewable energy sources, technologies for obtaining both thermal and power energy are gaining momentum. The main consumers of heat energy in Ukraine are housing and 
utilities services $60-65$ [3]. In Ukraine, the main energy products for the electricity and heat generation are coal and gas. Currently, there is a tendency towards the closure of unprofitable mines, but the domestic experience of coal industry restructuring is negative [4]. Liquidation of mining enterprises leads to an acute social situation, which is associated with unemployment, resource shortages and degradation of settlements. Environmental impacts of coal mining require significant costs for their elimination. The solution of these problems is to extend the life of mining enterprises by implementing RES [5].

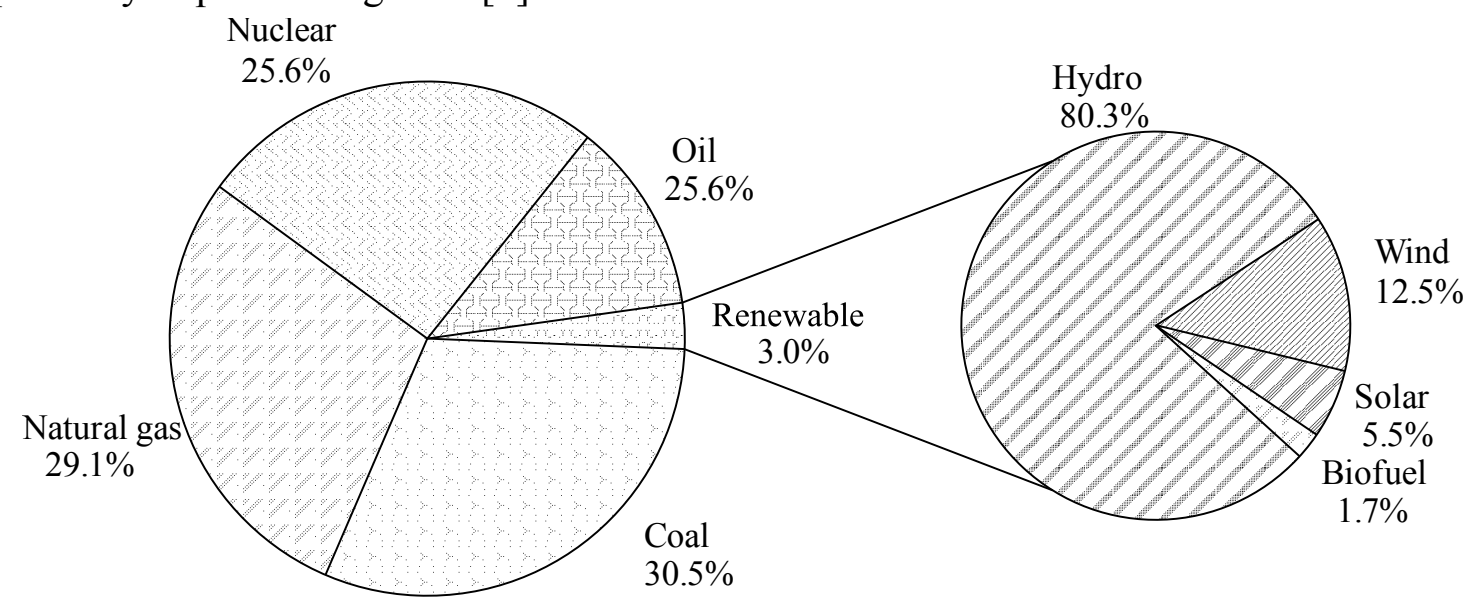

Fig. 2. Distribution of energy sources and structure of electricity production from renewable sources

At mining enterprises there are various powerful sources of exhaust heat: compressor, ventilation and boiler installations, mine water, outlet ventilation jet and others. The ease of access to them makes them very attractive additional sources of energy and heat $(6,7)$. Utilization of waste heat reduces the cost of fossil energy resources for electricity and heat production, reduces atmospheric pollution by carbon dioxide emissions and toxic gases at power boiler plants. At mining enterprises, exhaust heat can be used to heat the air supplied to the mine, in systems of heating and hot water supply, etc. The rationale of a technical solution for the use of this heat is determined, first of all, by the potential of this heat and the availability of relevant heat consumers at the mining enterprises (8-10).

\section{Recent Research and Publications Analysis}

Increasing the potential of technological solutions of heat recovery is mainly ensured by the introduction of heat pump plants. Their exploitation allows to create the technical bases of integrated energy-saving systems of year-round heating and conditioning of underground and surface structures of a mining enterprise with seasonal accumulation of excess heat energy in underground accumulators in the summer and subsequent use of it for heat supply during the heating season [11]. Information that contain development and research of the efficiency of heat pump plants usage is given in Table 1 [12].

Table 1. Distribution of information for the development and research the efficiency application of heat pump plants

\begin{tabular}{clc}
\hline No. & \multicolumn{1}{c}{ Information data } & Share, \% \\
\hline 1 & $\begin{array}{l}\text { Design and research of the efficiency of heat supply systems with heat pumps (HP), } \\
\text { development of technical solutions }\end{array}$ & 41.9 \\
2 & $\begin{array}{l}\text { Economic preconditions for the HP usage, technical and economic evaluation of the } \\
\text { HP system efficiency }\end{array}$ & 17.6 \\
3 & Tasks of HP implementation, including in the climatic conditions of Ukraine & 17.5 \\
4 & HP as a part of energy and resource conservation & 12.2 \\
5 & Possibilities and efficiency of thermal energy usage in thermal schemes of industrial & 5.4 \\
6 & Enterprises & 5.4 \\
\hline
\end{tabular}


The main sources of low temperature for HP are water, atmospheric air, soil and steam. The most used heat source for heat pumps is water [13]. The share of heat pumps operating on this lowcapacity heat carrier is $61 \%$, and on the soil and steam only $3 \%$. It should be noted that the soil massif is a powerful thermal battery of unlimited capacitance [14], but the temperature potential of the soil near the surface is small and is approximately $10-20^{\circ} \mathrm{C}$. It is rational to use the energy with this potential through the heat exchange circuit of the heat pump plant for industrial and municipal heat supply.

The method of earth's interior heat utilization, which includes heating circuit in the heat supply unit of the heat pump installation, is well known. The source of heat is underground mine waters with their natural temperature [15].

In the structure of mines expenditures for coal production, a considerable part is the cost of functioning of ventilation and air conditioning systems. At the same time, the possibility of increasing the efficiency of these systems by traditional methods is practically exhausted.

The outlet ventilation stream from mine maintains thermal energy, which is formed by contacting an air stream with warm rocks and working process equipment. Therefore, utilization of low-potential waste heat of the outlet ventilation streams from mines is an urgent task, since this energy is irretrievably lost [16]. HP installations usage in the cold season can significantly reduce both its own energy demand and the financial cost of energy supply of stationary installations that provide the external air heating before it is supplied to the mine. Minimal operating costs will be incurred when the entire heated load of the mine is covered with the HP system.

Another source of thermal energy in the mining enterprise is the use of energy potential of rock waste dump. There are approximately more than 1200 rock waste dump on the territory of Ukraine, which is a simple and additional source of thermal energy. In recent years, a number of technological solutions have been developed for the heat utilization from them.

In the work [17] was developed and proposed a technological scheme of heat pump installation for the continuous selection of heat by a low-temperature coolant from the heatgenerated zone of the extinguished heated rock waste dump. The main disadvantage of this technological scheme is that the soil heat exchanger, which is presented as a through pipe, directly contacts the batting rock, which leads to its corrosion under the influence of chemical reactions of oxidation and recovery. In addition, due to the operation of the soil heat exchanger pipe, the geomechanical and temperature factors that cause its deformation are affected by the operation [18].

Another technical solution is a known method for collecting heat from a rock waste dump, which is implemented by means of a heat recovery unit from the waste dump [19] containing a soil heat exchanger made from a register of welded metal pipes placed in reinforced concrete trays filled with bulk material, closed with concrete slabs, installed at the base of the forming turbine. The main disadvantages of this method of thermal energy removal is the possibility of locating the heat exchanger in the already formed rock waste dump, low coefficient of thermal conductivity of reinforced concrete trays.

\section{Unsolved Aspects of the Problem}

Rock waste dump from mining enterprises, not used in the process of manufacturing the main products, does not always lose its value. It can also be attributed to such waste. It has accumulated not only the potential for building materials, metals and rare earth elements, but also for the generation of thermal energy. Development of innovative directions for the creation of technological schemes for the integrated use of the geosystem for the production of thermal energy with the help of pumps can increase the efficiency of mining enterprises and their economic performance. After analyzing the existing experience of the rock waste dump development for the selection of thermal energy from them, the author of the work found a number of technological imperfections, which prompts technological improvement. It is expedient to consider a heat pump unit, which utilizes low-potential heat not as a separate segment of the mining industry, but as a heat pump geosystem. 


\section{Results and Discussion}

Significant savings in organic fuels and energy can be obtained with the widespread use of low-potential heat of rocks in mines in heat pump geosystems. They provide cogeneration of electricity, thermal and mechanical energy. For energy-saving technologies there is a significant interesting natural geosystem in a complex with HP installations and generated gases of borehole underground coal gasification (BUCG) [20]. The principle of operation of this technological development is based on the thermal energy utilization of gasification products (the temperature of the outlet gases is $600-800^{\circ} \mathrm{C}$ ) and the tank-battery of heat. It allows simultaneously to effectively apply two sources of energy for heat supply (Fig. 3).

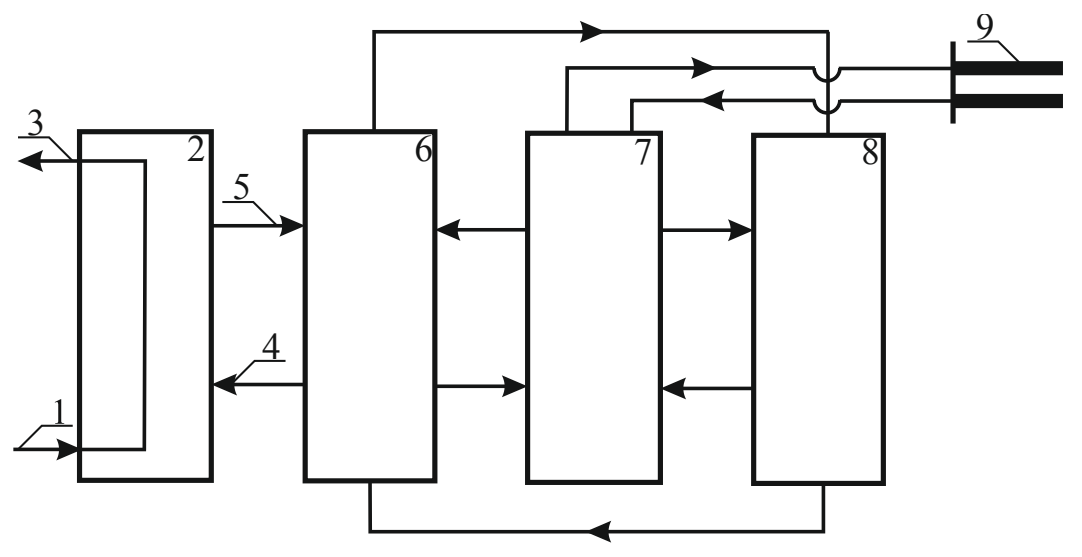

Fig. 3. Scheme of heat pump geosystem of power supply with well-rock heat exchangers:

1 - gas from BUCG; 2 - heat exchanger on heat pipes; 3 - output of UCG gas to the consumer;

4 - liquid intermediate coolant (cold water); 5 - hot water cooler: 6 - tank-accumulator;

7 - HP installation; 8 - the site of heat supply; 9 - earth surface; 10 - well-rock heat exchangers

Gas of BUCG 1 is formed underground by combustion (gasification) of coal seams by underground gasification. The essence of the BUCG is to drill wells, to incite the coal seam, to blast air for the coal combustion, to obtain generator gases, which is passed through the wells to the surface [21]. Next, gas 1 is fed into a heat exchanger 2 for utilizing heat and gas and for receiving hot water 5 . Water enters the tank-battery 6 . Hot heat transfer medium through heat pump units 7 is fed to the municipal heat supply system 8 .

The main purpose of the well hole heat exchangers 10 is the selection of low-potential thermal energy accumulated in the rock or soil. Further transmission of this thermal energy to the consumer 8 , but already at a higher temperature level, occurs with the use of the possibilities of the heat pump cycle. In systems of soil heat exchangers, the amount of received heat energy depends on the speed, pressure, type of fluid circulating in the system, its physical properties, the number of soil pipes, the distribution of temperatures in the soil, the characteristics of the heat transfer process, which affects the temperature of the heat carrier, from which in turn, the temperature of the coolant at the outlet of the soil heat exchanger depends.

Execution of soil heat exchangers can be both vertical and horizontal arrangement [22]. The choice of heat exchanger type is determined by the needs and capabilities of the heat consumer. In a geosystem that uses a large number of vertical rock tubes, they can be arranged in a form that has a hexagonal configuration. The distance between the pipes of the rock geosystem, which is created in mining operations of mines and other underground structures, is determined by the existing area. It can be taken $0.5-2.0 \mathrm{~m}$. Vertical heat exchangers are installed from pipes of different diameters, which set one in the other. The location of pipe wells in the corners and the hexagon center, allows to effectively increase the energy accumulated in the rocks in the organization of counter-directed heat fluxes. The cold coolant moves from the top to the bottom in the inner tube, and from the bottom to the upward - a hot coolant in the inter-tube ring space. Rocks or soil heat exchangers are usually made of polyethylene or steel seamless pipes. 
In order to improve the efficiency of the heat pump geosystem, the author of the work is proposed to carry out the selection of heat from rock waste dumps. This will enable to improve the component segment of the heat pump geosystem (Fig. 3, section 7,9). Therefore, existing technological and schematic solutions for heat recovery from rock waste dump were analyzed and a new technological scheme for obtaining thermal energy was developed.

The scheme was based on the task of improving the method for selecting heat from already formed non-burning, burning and extinguished rock waste dump in coal mines, surface mining and processing plants. By introducing new technological operations and parameters, it is possible to obtain heat energy at any level with the development of the whole rock waste dump. This affects the increase in the capacity of the heat pump plant as a whole, while reducing costs.

The method for collecting heat from a coal mine, a section or a mining and processing plant include the installation of a heat exchanger element in the dump. Pre-determine the temperature field of the formed dump, the required number of elements of the heat-exchange system, the capacity of the heat pump installation. At the selected level, drilling wells in a formed dump with a suction casing, in which the elements of the heat exchange system are mounted [23]. This technological scheme is shown in Figure 4.

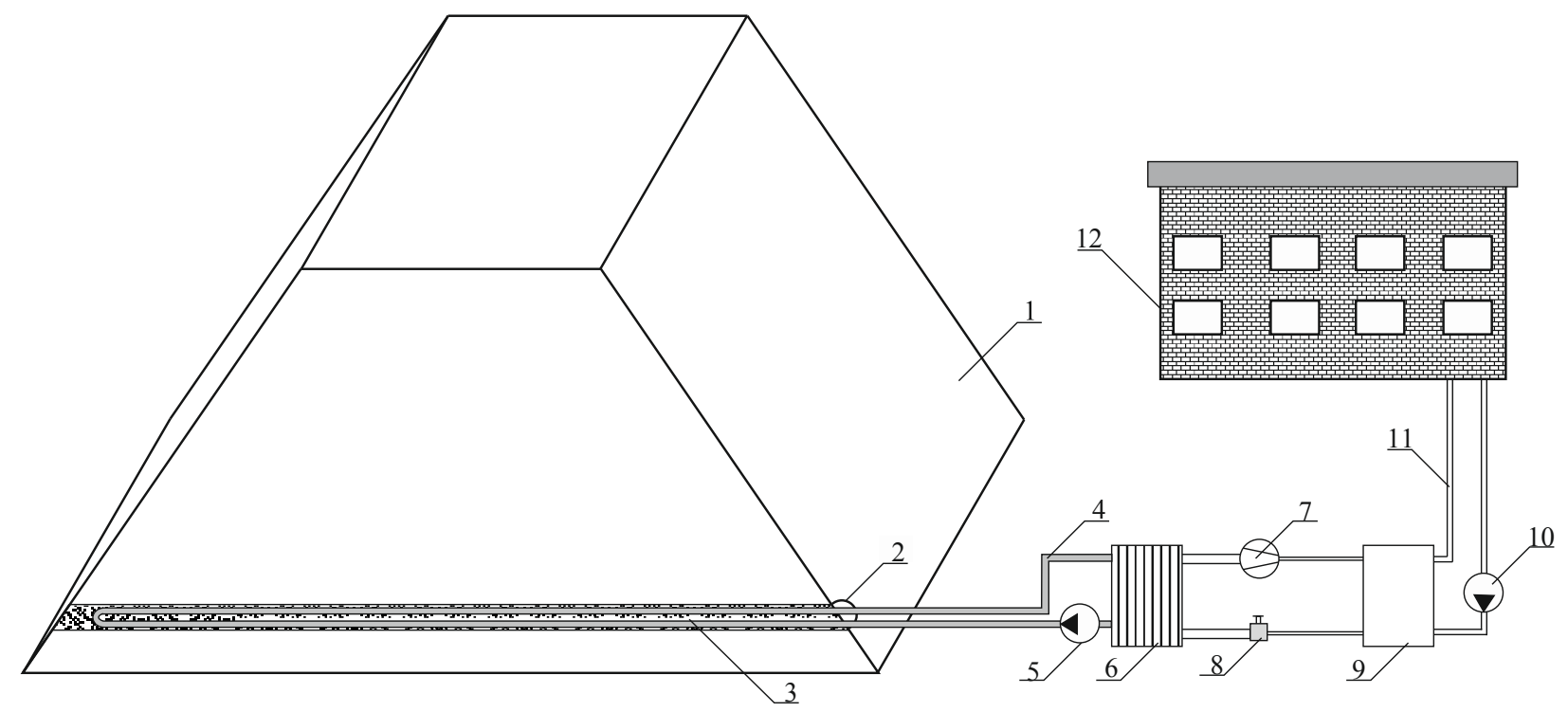

Fig. 4. The technological scheme of heat recovery from the rock waste dump: 1 - a dump, 2 - a casing pipe, 3 - a bulk filler, 4 - elements of a heat exchange system, 5, 10 - circulating pumps, 6 - evaporator, 7 - a compressor, 8 - a throttle valve, 9 - condenser, 11 - heat supply pipelines, 12 - heat supply customer

Before the process of horizontally directed wells and installation of elements of the heat pump system, preliminary study the temperature field of the formed dump and set the necessary number of elements of the heat exchange system, based on the power of the heat pump installation. After that, horizontally-directed drilling drills number of wells at the selected level of the formed dump. Conduct their reinforcement with the casing 2 with the arrangement in it of the element of the heat exchange system 4 . Free space in the casing 2 is filled with loose material, such as sand [24]. The circuit of the element of the heat exchange system 4 with the installed circulation pump 5 is connected to the evaporator 6 , which through the compressor 7 and the throttle valve 8 is connected to the condenser 9. From the condenser 9, the heat supply system 11 pipelines on which the circulating pump 10 is installed, after which the pipelines of the heat supply system are brought to the customer of heat supply 12 .

The heat from the dump 1 is transmitted through the casing 2 and the loose material of the 3 elements of the heat exchange system 4 , in which a circuit pump 5 is installed, which pumps the heat carrier, which removes the thermal energy and transports it to the evaporator 6 . As a coolant, it is possible to use technical water. In the evaporator 6 , the received heat energy is selected, which circulates in the circuit between the evaporator 6 and the condenser 9 with the help of a compressor 
7 and a throttle valve 8 . This contour is filled with freon. The resulting hot air vapor frees are transmitted by the heat in the condenser 9 of the heat supply system 11 , connected to the heat supply customer 12. The circulation in the heat supply system is carried out with the help of a circulation pump 10. To control the temperature and expenditure of the heat generated from the waste heap, throttle valve 8 . The heat removal from the dump is carried out all over its area. The accumulated heat from the dump according to the technological scheme and the parameters of the temperature field formation in the dump, directed to a specific customer, taking into account the seasonal needs of thermal energy.

The developed technological scheme of heat recovery from the dump is an integral part of the geosystem of supply on the basis of underground coal gasification technology. The efficiency of this geosystem of heat supply is characterized by the thermal coefficient of energy conversion $k$ :

$$
k=\frac{Q}{A},
$$

where $\mathrm{Q}$ - amount of heat using the heat pump evaporator, $\mathrm{MJ} / \mathrm{kg}$;

$A$ - the work that is spent on compressing freon in the compressor of the pump, $\mathrm{MJ} / \mathrm{kg}$.

The use of energy emitted from the soil or rock massif by means of soil or well rock heat exchangers and directed to the evaporator of a heat pump, allows to increase the energy transformation, which increases the efficiency and reliability of the entire geosystem of alternative heat and electricity supply.

To substantiate the feasibility of introducing a geosystem, it is necessary to determine the soil temperature in advance:

$$
T=T_{0} \pm \Delta T_{0}+1.07 k A_{t} \exp \left(-0.000316 h\left(\frac{1}{a}\right)^{\frac{1}{2}}\right) \cos \left[\left(\frac{2 \pi}{365}\right)\left(n-n_{0}-0.01834 h\left(\frac{1}{2}\right)^{\frac{1}{2}}\right)\right],{ }^{\circ} \mathrm{C}
$$

where $T_{0}$ - average annual temperature of the ambient air, ${ }^{\circ} \mathrm{C}$;

$\Delta T_{0}$ is temperature correction for the specifics of the region concerned, ${ }^{\circ} \mathrm{C}$;

$k$-dimensionless factor taking into account the degree of soil coverage by vegetation;

$A_{t}-$ amplitude of oscillation of the average monthly temperature of air, ${ }^{\circ} \mathrm{C}$;

$h$ - soil depth, m;

$a$ - temperature conductivity of the soil $\mathrm{m}^{2} / \mathrm{s}$;

$n$ - number of the day of the year;

$n_{0}$ - the duration of the phase change in the amplitude of temperature fluctuations, days.

Energy indicators of the alternative cogeneration power system geosystem can be greatly improved with the use of heat from rock heat exchangers to provide settlements with hot water supply throughout the year and the deep utilization of heat of exhaust flue gases.

\section{Conclusions}

The proposed method of heat selection from the formed coal mine dumps allows to significantly increase the energy efficiency of the heat pump geosystem on the basis of underground coal gasification. Construction of a geosystem with the selection of heat from dumps will make it possible to autonomously provide electric, thermal and mechanical energy settlements located around mines. For this purpose, the technology of borehole underground coal gasification of coal seams and heat pump geosystem of power supply with well-formed rock heat exchangers, located also in mine workings, may be involved. A new energy saving technological scheme has been created, taking into account the possibility of using several alternative environmentally friendly energy sources, among which the most promising is the gas energy of borehole underground coal gasification and the heat of mine dumps and rocks in an alternative cogeneration energy saving system. 


\section{Acknowledgements}

This work was supported by the Ministry of Education and Science of Ukraine, grants No. $0116 \mathrm{U} 008041$ and No.0115U002293.

\section{References}

[1] Bondarenko, V., Lozynskyi, V., Sai, K., \& Anikushyna, K. (2015). An overview and prospectives of practical application of the biomass gasification technology in Ukraine. New Developments in Mining Engineering 2015, 27-32. https://doi.org/10.1201/b19901-6

[2] State Statistics Service of Ukraine. Available online: http://www.uabio.org/img/files/news/pdf/ energy-balance-ukraine-2015.pdf

[3] Bilodid, V.D. (2015). Vyroblennia ta spozhyvannia teplovoi enerhii v Ukraini u 2005-2013 rokakh. Problemy zahalnoi enerhetyky, 1(40). 39-46.

[4] Petenko, A.V. (2014). Promyslovo-ekolohichna kontseptsiia upravlinnia protsesamy sotsialnoho rozvytku ekolohoskladnykh vuhlepromyslovykh rehioniv Donbasu. Visnyk sotsialno-ekonomichnykh doslidzhen, 1(52), 55-60.

[5] Falshtynskyi, V.S., Dychkovskyi, R.O., Tabachenko, M.M., Saik, P.B. (2011). Sposoby rekuperatsii tepla porid pry pidzemnii hazyfikatsii vuhillia. Naukovo-tekhnichnyi zbirnyk Hirnycha elektromekhanika i avtomatyka, 86. 184-190.

[6] Zhamoida, O. (2016). Managing mining enterprises' assets as the basis of their competitiveness. Mining of Mineral Deposits, 10(4), 50-55. https://doi.org/10.15407/mining10.04.050

[7] Brady, B. H. G., \& Brown, E. T. (2007). Energy, mine stability, mine seismicity and rockbursts. Rock Mechanics for Underground Mining, 271-311.

[8] Bondarenko, V., Cherniak, V., Cawood, F., \& Chervatiuk, V. (2017). Technological safety of sustainable development of coal enterprises. Mining of Mineral Deposits, 11(2), 1-11. https://doi.org/10.15407/mining11.02.001

[9] Perkov, Ye., \& Perkova, T. (2017). Recycling of Prydniprovska thermal power plant fly ash. Mining of Mineral Deposits, 11(1), 106-112. https://doi.org/10.15407/mining11.01.106

[10] Samusia, V., Kyrychenko, V., Kyrychenko, Ye., Ilina, S., \& Antonenko, A. (2017). Hydrothermodynamic model of deep-water hydraulic lift of 3-phase fluid considering heat-massexchange processes. Mining of Mineral Deposits, 11(2), 96-102. https://doi.org/10.15407/mining 11.02 .096

[11] Underwood, C. P. (2016). Heat pump modelling. Advances in Ground-Source Heat Pump Systems, 387-421. https://doi.org/10.1016/b978-0-08-100311-4.00014-5

[12] Tkachenko, S.I., Ostapenko, O.P. (2007). Systematyzatsiia informatsii z rozrobky, doslidzhennia ta vprovadzhennia teplonasosnykh ustanovok. Suchasni tekhnolohii, materialy $i$ konstruktsii $v$ budivnytstvi: naukovo-tekhnichnyi zbirnyk, 4, 176-184.

[13] Krukovskyi, O., Krukovska, V., \& Vynohradov, Yu. (2017). Mathematical modeling of unsteady water filtration into anchored mine opening. Mining of Mineral Deposits, 11(2), 21-27. https://doi.org/10.15407/mining11.02.021

[14] Turkyilmazoglu, M. (2018). Heat transfer from moving exponential fins exposed to heat generation. International Journal of Heat and Mass Transfer, 116, 346-351. https://doi.org/10.1016/j.ijheatmasstransfer.2017.08.091

[15] Tabachenko, M.M., Dychkovskyi, R.O., Falshtynskyi, V.S. (2010). Sposib utylizatsii tepla nadr. Patent No 50712, Ukraine

[16] Tabachenko, M., Saik, P., Lozynskyi, V., Falshtynskyi, V., \& Dychkovskyi R. (2016). Features of setting up a complex, combined and zero-waste gasifier plant. Mining of Mineral Deposits, 10(3), 37-45. http://dx.doi.org/10.15407/mining10.03.037

[17] Macevytyi, Ju.M., Chyrkin, M.B., Cencyper, A.I. (2009). Teplonasosna ustanovka. Patent No. 85929, Ukraine 
[18] Nitsche, M., \& Gbadamosi, R. O. (2016). Geometrical Heat Exchanger Calculations. Heat Exchanger Design Guide, 65-74. https://doi.org/10.1016/b978-0-12-803764-5.00004-3

[19] Macevytyi, Ju.M., Chyrkin, M.B. (2012). Ustanovka dlia vidboru tepla z terykonu. Patent No. 100181, Ukraine.

[20] Falshtynskyi, V., Dychkovskyi, R., Lozynskyi, V., \& Saik, P. (2015). Analytical, laboratory and bench test researches of underground coal gasification technology in National Mining University. New Developments in Mining Engineering 2015, 97-106. https://doi.org/10.1201/b19901-19

[21] Falshtynskyi, V., Lozynskyi, V., Saik, P., Dychkovskyi, R., \& Tabachenko, M. (2016). Substantiating parameters of stratification cavities formation in the roof rocks during underground coal gasification. Mining of Mineral Deposits, 10(1), 16-24. http://dx.doi.org/10.15407/mining10.01.016

[22] Dychkovskyi, R., Falshtynskyi, V., Lozynskyi, V., \& Saik, P. (2015). Development the concept of borehole underground coal gasification technology in Ukraine. New Developments in Mining Engineering 2015, 91-95. https://doi.org/10.1201/b19901-18

[23] Saik, P.B., Lozynskyi, V.H., Dychkovskyi, R.O., Falshtynskyi, V.S. (2017). Sposib vidboru tepla z vidvaliv. Patent No. 113313, Ukraine.

[24] Kuzmenko, O., Petlyovanyy, M., \& Heylo, A. (2014). Application of fine-grained binding materials in technology of hardening backfill construction. Progressive Technologies of Coal, Coalbed Methane, and Ores Mining, 465-469. 